Арктики: тез. докл. І междунар. конф. Екатеринбург: Деловая пресса, 2017. С. 57-60.

25. Herz N., Garrison E.G. Geological methods for archaeology. Oxford: University Press, 1997. 343 p.

26. Номоконова Т.Ю. и др. Хозяйственная деятельность населения Нижнего Приобья в эпоху энеолита (по фаунистическим материалам поселения Горный Самотнел-1) // Вестник археологии, антропологии и этнографии. 2017. № 1 (36). С. 143-150.
27. Тупахина О.С., Тупахин Д.С. Реконструкция социально-экономических отношений в энеолите Западносибирского Заполярья по результатам междисциплинарных исследований поселения Горный Самотнел-1 // Труды V (XXI) Всероссийского археологического съезда в Барнауле - Белокурихе: сборник научных статей: в 3 т. / отв. ред. А.П. Деревянко, А.А. Тишкин. Барнаул: Изд-во Алт. ун-та, 2017. T. III. C. $85-89$.

\title{
ROLE OF FISHING IN THE FINAL STONE AGE OF THE LOWER OB REGION (ON THE MATERIALS OF THE SETTLEMENT GORNY SOMATNEL - I)
}

(C) 2018

Tupakhina Olga Sergeevna, candidate of historical sciences, senior researcher of Archaeology Department

Tupakhin Daniel Sergeevich, junior researcher of Archaeology Department Arctic Research Center (Salekhard, Russian Federation)

Abstract. The role of fishing in the human history is very high. Though meat is considered to be an important product of hunting, fish has been a basic component of the food system of human groups in different climatic and geographical conditions. This is explained by the fact that groups lived next to water resources (lakes, rivers, seas, oceans) that had a high nutritional value. The first evidence of fishing existence as an independent economic sector belongs to the Paleolithic time, and its further development goes throughout human history, having developed from the simplest forms of fishing using primitive harpoons to modern forms of industrial fishing using a specialized fleet. The period under review, final Stone Age, is characterized by massive use of fishing nets. We assume that this method became a base of effective adaptation strategy, making it possible to develop the Lower Ob area with its difficult climate. The issues raised in this paper involve the role and importance of fishing economy for West Siberian North as well as for ancient economies of the North and Arctic regions.

Keywords: ancient adaptation strategy; fishing net; Lower Ob region; economic adaptation; sedimentary fishing; aquatic resources exploitation; Arctic archaeology; faunistic remains analysis; stable isotopes pottery analysis.

\section{КЛЮВОВИДНЫЕ ПРЕДМЕТЫ И ОРУДИЯ РЫБНОЙ ЛОВЛИ ИЗ РИТУАЛЬНЫХ «КЛАДОВ» ВОЛОСОВСКОЙ КУЛЬТУРЫ СО СТОЯНКИ САХТЫШ-І (ЦЕНТРАЛЬНАЯ РОССИЯ)} (C) 2018

Костылёва Елена Леонидовна, кандидат исторических наук, доцент кафедры истории России Ивановский государственный университет (г. Иваново, Российская Федераџия)

Мацане Айя, аспирант исторического факультета Университет Гётеборга (г. Гётеборг, Королевство Швеция)

Аннотащия. Могильник Сахтыш-ІІ (Центральная Россия) относится к финальному этапу развития волосовской культуры эпохи энеолита. Он исследовался в 1960-1980 годы Верхневолжской экспедицией ИА РАН. На его территории было обнаружено около двадцати ритуальных «кладов». Они представляли собой скопления артефактов со следами воздействия огня. Среди них находились и разнообразные орудия рыболовства: зубчатые острия, гарпуны, рыболовные крючки. Мы полагаем, что клювовидные изделия из кости, назначение которых до сих пор дискутируется, также являются гарпунами. Разнообразие форм орудий может говорить о специализации в области рыболовства. Время сокрытия «кладов» определяется радиокарбоновыми датами по образцам угля из ритуальных кострищ: $3820 \pm 40,3900 \pm 40$ и $4190 \pm 50$ ВР (Ле-2617, 2613, 2615). Однако по костям животных (медведь и барсук) из двух «кладов» (№№ 9 и 11) в 2017 году в лаборатории Белфаста были получены новые AMS даты: $4730 \pm 41$ и $4445 \pm 37$. Достаточно существенное различие новых дат с предыдущими может быть связано с резервуарным эффектом, обусловленным тем, что в рационе питания этих всеядных животных присутствовала рыба. А также с тем, что эти два клада, расположенные вне зоны основных ритуальных площадок, относятся к более раннему времени.

Ключевые слова: Центральная Россия; Ивановская область; энеолит; волосовская культура; могильник Сахтыш-ІІ; ритуальные клады; орудия рыболовства; рыболовные крючки; гарпуны; клювовидные изделия неясного назначения; радиоуглеродные даты; проблема достоверности дат; резервуарный эффект.

Памятник археологии Сахтыш II, входящий в состав сахтышского археологического комплекса, находится в центре Русской равнины (Ивановская обл.) (рис. 1). Он располагается на левом берегу р. Койка, вытекающей из палеоозера Сахтыш (рис. 2). Памятник является многослойным (мезолит - ранний железный век) и полифункциональным (стоянка, посе- ление, могильник, святилище). Он исследовался в 1960-1980 гг. Верхневолжской экспедицией ИА АН СССР под руководством Д.А. Крайнова.

Специальных публикаций поселенческих материалов сравнительно немного [1; 2]. Обычно в контексте более широких исследований представлялись наиболее яркие артефакты, связанные с бытом, про- 
Костылёва Е.Л., Мацане А.

Клювовидные предметы и орудия рыбной ловли из ритуальных «кладов» . 07.00 .00 - исторические науки и археология изводственной деятельностью, религиозными представлениями и искусством [3-8]. А вот могильник и сопровождавшие его ритуальные комплексы были нием нескольких «кладов» из раскопок 1960-х годов ввиду отсутствия доступа к коллекциям и утрате опубликованы практически полностью (за исключе-

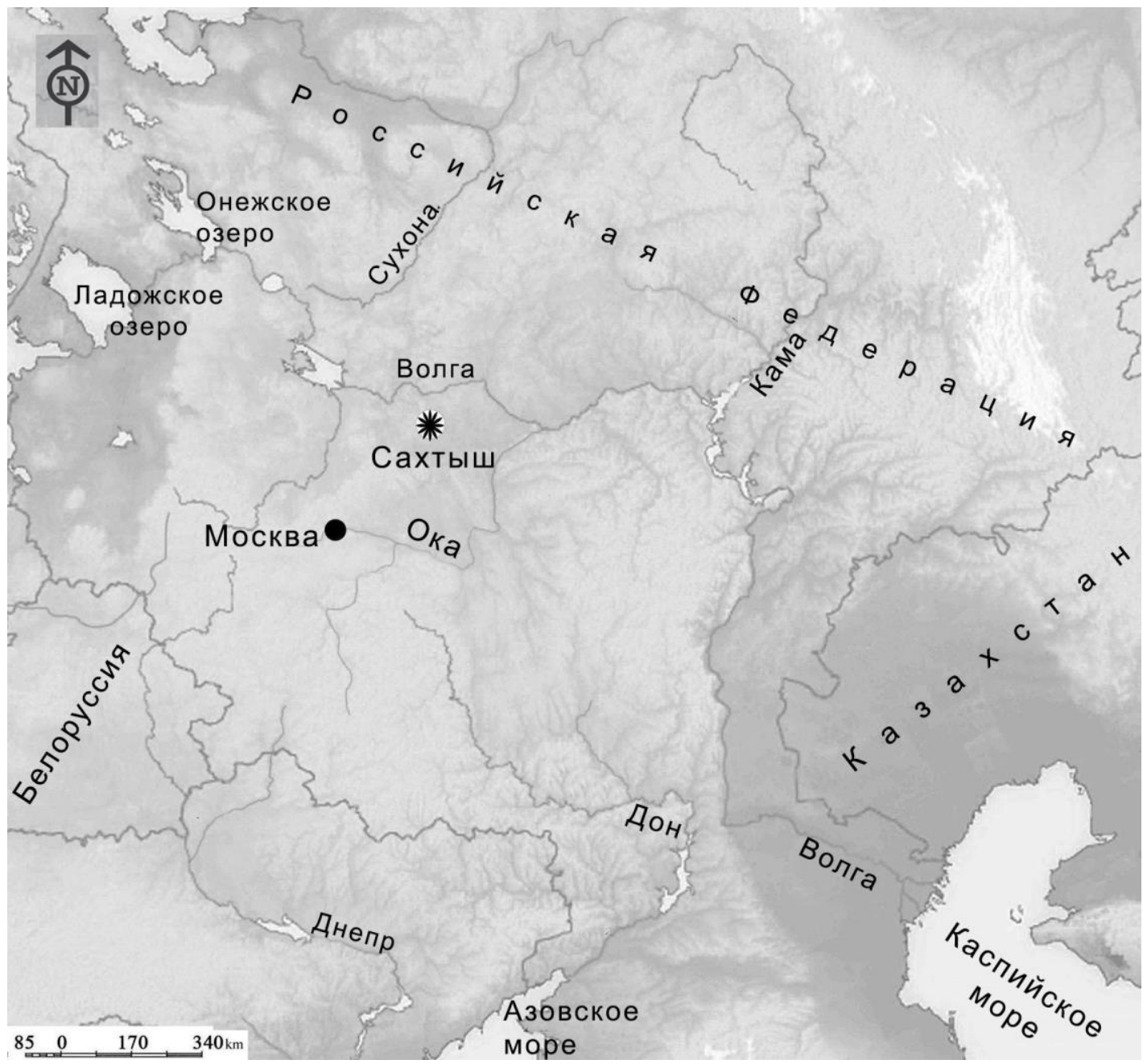

Рисунок 1 - Карта расположение сахтышского археологического комплекса

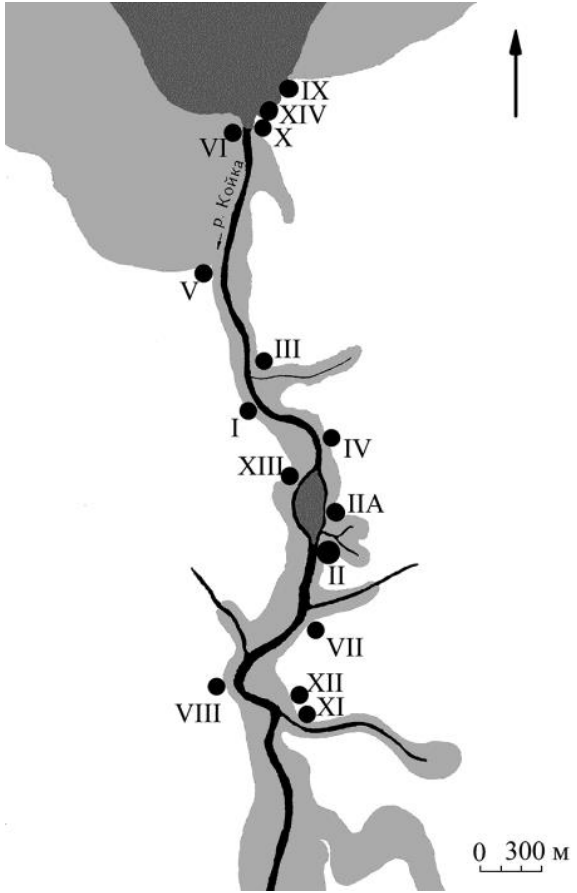

Рисунок 2 - Схема расположения памятников сахтышского археологического комплекса (рис. А.В. Уткина)
За годы работ на памятнике было вскрыто 26 захоронений, 22 из которых относятся к финальной стадии развития волосовской культуры [13, с. 15-23]. Частью погребального обряда древних «волосовцев» являлось создание рядом с могилами ритуальных «кладов», которые, видимо, представляли собой погребальный инвентарь. Однако этот инвентарь помещался не в могильную яму, а рядом с ней. Всего на Сахтыше II было обнаружено около 20 «кладов». Более точную цифру назвать трудно, т.к. нет точных данных по «кладам» 1960-х годов (рис. 3).

Подобные комплексы (погребения с «кладами») были исследованы в свое время на стоянке Володары (Нижегородская обл.) И.К. Цветковой [14]. Они обнаруживают значительную близость с материалами Сахтыша II, что может быть обусловлено отнесением их к единому культурно-хронологическому пласту. Ритуальные «клады» были найдены и на стоянке Сахтыш VIII, однако там они были связаны не с погребальными, а с жилищными комплексами и не содержали предметов из органических материалов [15].

Почти все погребальные «клады» Сахтыша II нашли освещение в литературе $[10 ; 13 ; 16]$. Однако мы обращаемся к ним еще раз. «Клады» как закрытые комплексы, относящиеся к достаточно узкому культурно-хронологическому диапазону, позволяют 
выявить специфические особенности инвентаря, характерного для финального этапа развития волосовской культуры. Это чрезвычайно важный момент, т.к. на большинстве памятников центральной России материалы волосовской и предшествующей ей льяловской культур находятся в смешанных слоях и не разделяются стратиграфически. В результате трудно бывает определить культурную принадлежность вещей. Попытка определить культурную принадлежность орудий рыбной ловли была предпринята
Д.А. Крайновым в специальной статье, посвященной рыболовству у неолитических племен Верхнего Поволжья [17]. Однако привлечение материалов многослойных памятников со смешанным культурным слоем не позволило автору сделать это с достаточно высокой долей достоверности. Гораздо более успешной оказалась попытка В.М. и О.В. Лозовских вычленить кремневый и костяной инвентарь льяловской культуры на хорошо стратифицированном памятнике Замостье 2 в Подмосковье [18].

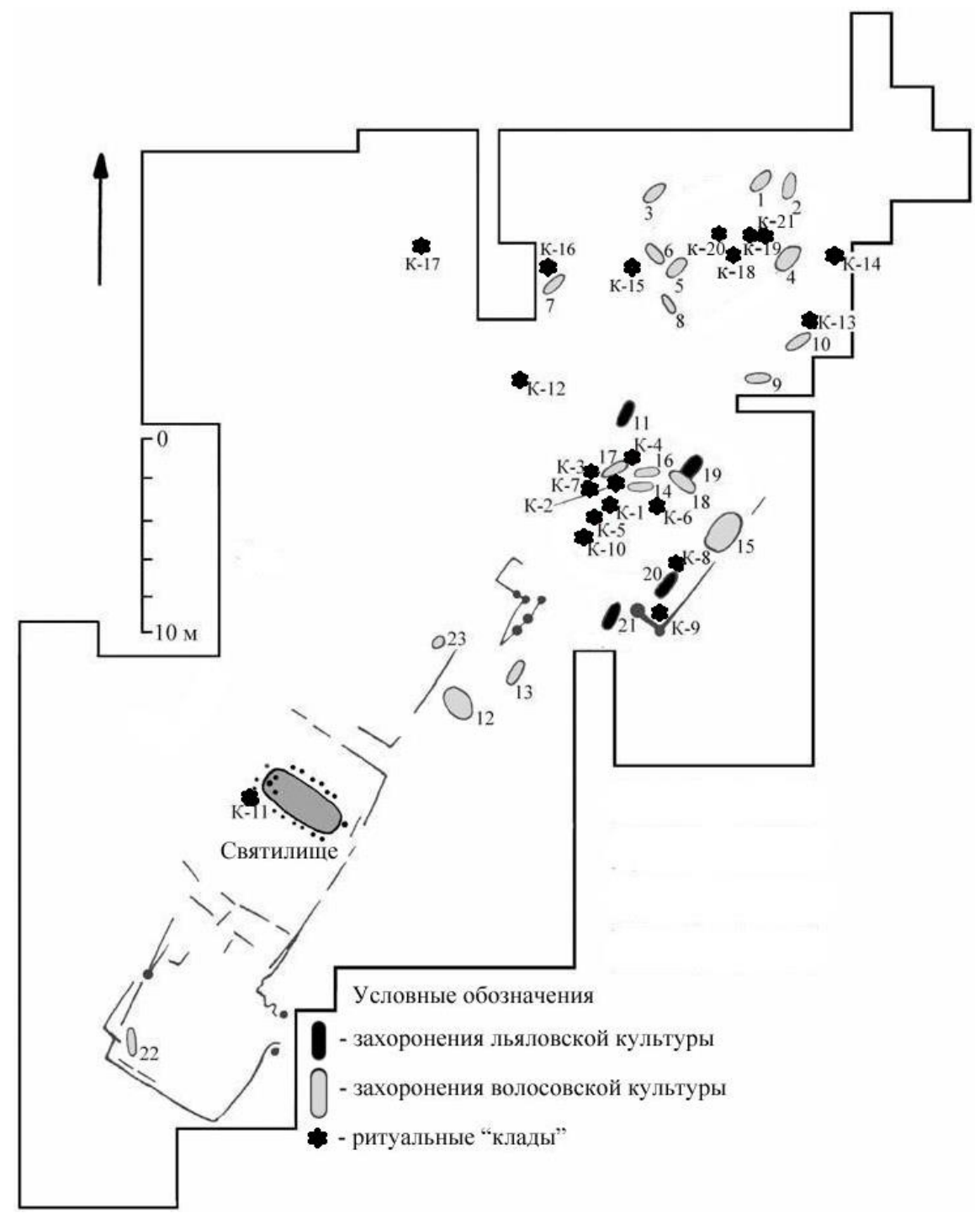

Рисунок 3 - План раскопов Сахтыша II с погребениями и ритуальными «кладами» (рис. А.В. Уткина, Е.Л. Костылёвой)

В настоящей статье мы ставим целью осветить среди многообразия предметов из «кладов» лишь одну категорию: орудия рыбной ловли. Они представлены в гораздо меньшем количестве, чем орудия охоты [13, с. 35-36], хотя рыболовство играло весьма существенную роль в хозяйственной деятельности населения волосовской культуры [17]. Такой дисбаланс, видимо, связан с тем, что в «кладах» представлены орудия лишь индивидуального лова рыбы, в то время как в реальной деятельности «волосовцев» большое значение имел лов рыбы другими приспособлениями, например сетями и вершами.

Рыболовный инвентарь был обнаружен в 9 «кладах» в количестве 22 экз. (рис. 4).

Все орудия сделаны из кости или, в меньшем числе, из рога. К ним относятся рыболовный крючок, зубчатые острия, крепившиеся жестко к древку остроги и имеющие на насадах порожки или ступеньки, препятствующие сползанию крепления с древка, а также гарпуны, у которых в нижней части есть отверстие для крепления линя.

К орудиям лова мы предлагаем отнести и особые артефакты, два из которых впервые были зафиксированы О.С. Гадзяцкой в двух «кладах» Сахтыша II в 1963 и 1964 гг. (рис. 4: 15, 16) и отнесены ею к предметам «неясного назначения» [1, с. 24-25]. Впоследствии во время раскопок памятника Д.А. Крайновым и Е.Л. Костылёвой в 1984 и 1985 гг. в трех «кладах» было найдено еще пять подобных предметов [13, c. 90, 93, 96]. Таким образом, всего на Сахтыше II они были обнаружены в 5 «кладах» - №№ 3, 8, 10, 12 и 20 в количестве 7 экз. (рис. 4: 14-20). 


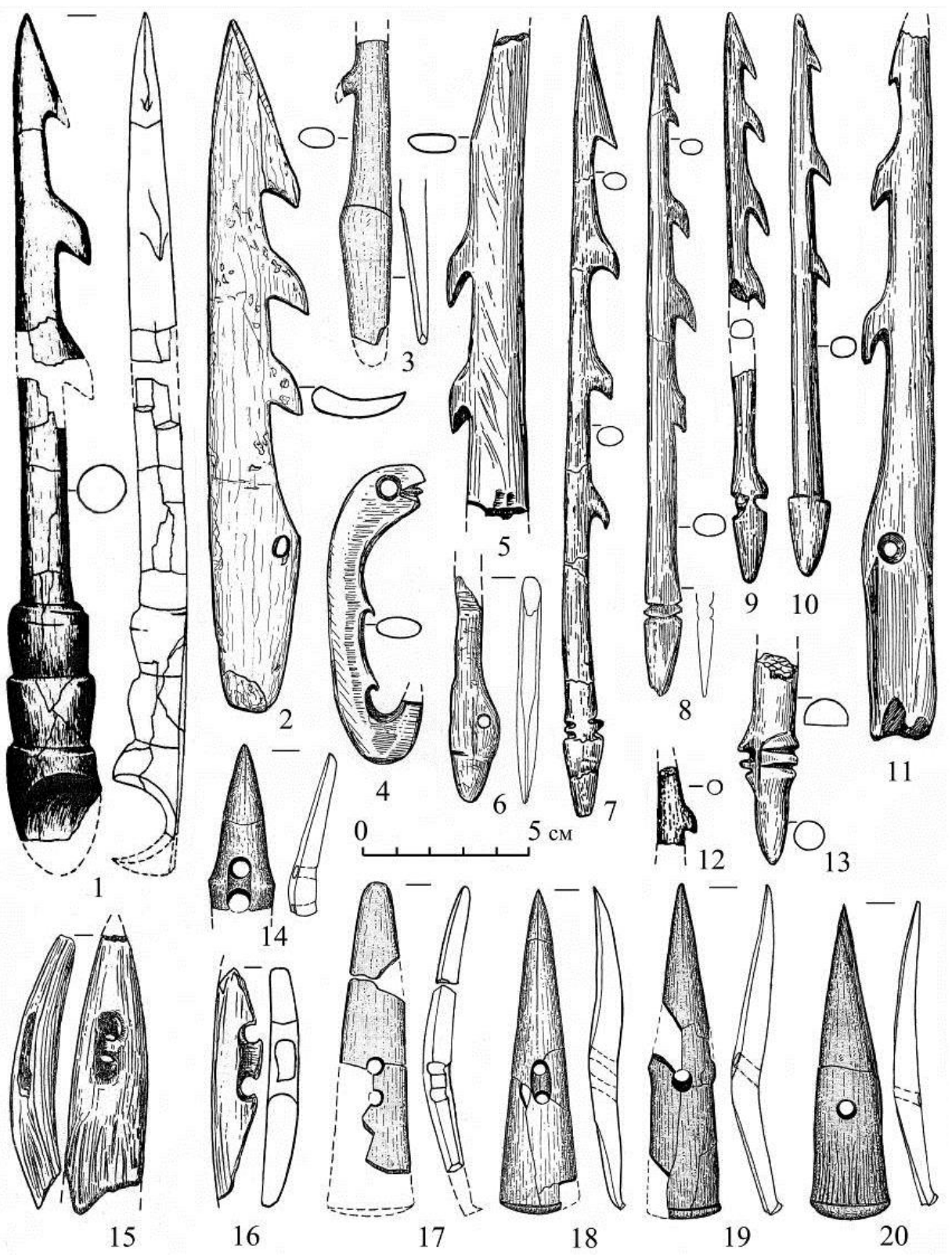

Рисунок 4 - Клювовидные предметы и орудия рыбной ловли из ритуальных «кладов» волосовской культуры со стоянки Сахтыш-II

(рис. А.В. Уткина - 1, 3, 12, 14, 17-20; Е.Л. Костылёвой - 2; 0.С. Гадзяцкой-4-11, 13, 15, 16)

Эти предметы представляют собой клювовидные заострения длиной около 10 см с двумя (реже - одним) отверстиями, расположенными по длинной оси. Между отверстиями с одной или двух сторон имеется желобок. На конце, противоположном острию, с внешней стороны орудия располагается порожек, предназначенный для удержания от сползания крепления (шнура), а с внутренней стороны - подтеска или выскабливание скребком под древко. Для большинства этих предметов характерен изогнутый профиль (рис. 5).

Кроме Сахтыша II, несколько таких орудий (не менее трех), как в целом виде, так и в обломках, были найдены на соседней стоянке Сахтыш I без четкой привязки к каким-либо комплексам.

По данным Е.А. Кашиной, подобные предметы были обнаружены в разных контекстах на 15 памятниках лесной зоны европейской части России в количестве 41 экз. [19, с. 486]. Еще два предмета: со стоянки Стрелка-I (Ивановская обл.) [20, с. 127 , рис. 10: 29] и Языково-І (Тверская обл.) - выпали из поля зрения исследовательницы. Со стоянки Языково-І упоминается лишь фрагмент изделия [19, с. 487]. Однако на памятнике был найден и целый предмет, представленный в археологической экспозиции музея г. Кимры Тверской области (не опубликован).

Среди археологов отсутствует единство в трактовке этих артефактов. Первую интерпретацию дал В.В. Сидоров, указав на их возможное использование в качестве охотничьих манков [21]. А.В. Уткин полагал, что это были детали ритуальных «птичьих» масок, а Е.Л. Костылёва предлагала считать их челноками для вязания сетей [13, с. 30]. Последнюю гипотезу применения этих артефактов предложила Е.А. Кашина [19]. По ее мнению, подобные предметы могли служить «накладками на концы рогов лука» $[19$, c. 488]. Правда, при этом было отмечено, что неясной остается роль острия [19, с. 491]. Кроме того, Е.А. Кашина, достаточно обстоятельно описав морфологию данных предметов, совсем не указала на такую важную деталь, как изогнутый профиль многих из них. 
Мы полагаем, что это могли быть гарпуны, в определенной мере сходные с поворотными гарпунами, которые появляются в эпоху раннего металла и широко распространяются в последующее время в культурах охотников на морского зверя [22; 23].
Особенно их сближает способ крепления линя через одно или два отверстия, между которыми имеется желобок [22, с. 174 , рис. $6: 12-14 ; 23$, рис. $11: 3$, рис. $12: 2,7$, рис. 13:3], (рис. 6)

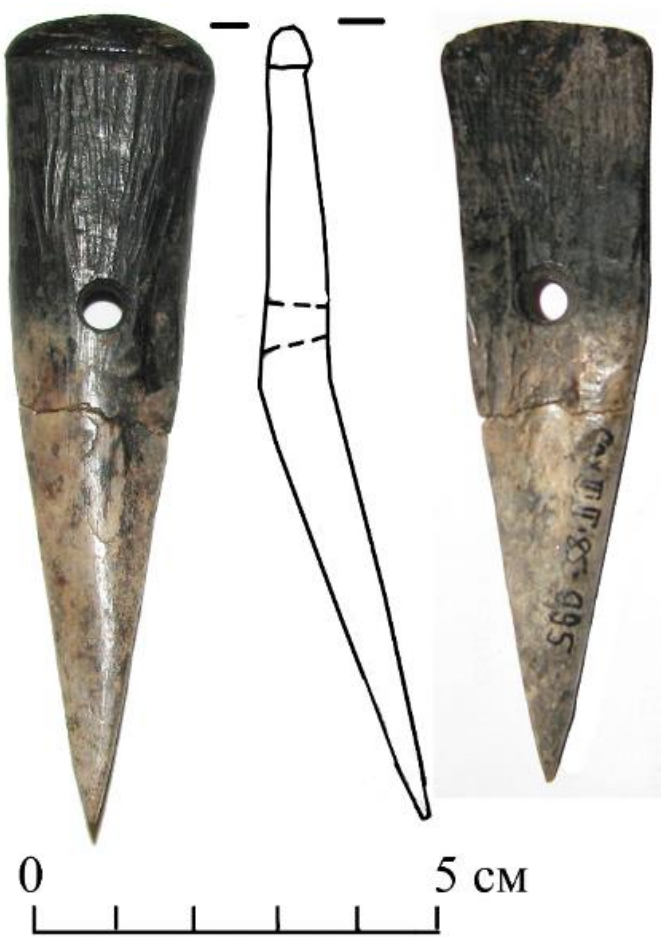

Рисунок 5 - Клювовидный предмет из «клада» № 10 со стоянки Сахтыш-II (фото и обработка Е.Л. Костылёвой)

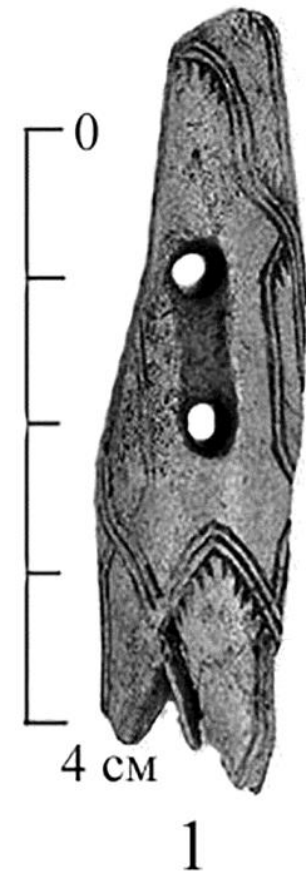

Рисунок 6 - 1 - костяной наконечник гарпуна беринговоморской культуры из фондов Сахалинского областного краеведческого музея (КП-8077-204 АРХ-205/204) [24];

2 - костяной наконечник гарпуна культуры пунук с сайта Brooklyn Museum [25]

Способ крепления такого гарпуна предполагал использование между наконечником и древком посредника (колка), который вставлялся в раструб (прорезь) древка и вместе с острием легко отделялся от него при попадании в добычу. Он мог быть как костяным, так и деревянным (рис. 6, 7).

Однако сахтышские орудия были не поворотными гарпунами, а гарпунами особого типа, которым мы предлагаем дать название «клювовидные» из-за их сходства с клювом птицы. Это сходство у ряда гарпунов усиливается их изогнутой формой, что хо-

рошо видно в профиле орудий. Данную особенность мы считаем важным изобретением волосовских охотников-рыболовов, т.к. изогнутость гарпуна компенсировала эффект преломления света в воде и тем самым увеличивала точность попадания в добычу. Подобные гарпуны могли использоваться как при ловле крупной рыбы, так и для лова бобра на воде. Однако при добыче крупной рыбы не имело большого значение, в какую часть туловища рыбы вонзится гарпун. При охоте же на бобра нужно было попасть точно в голову, чтобы не испортить шкуру.

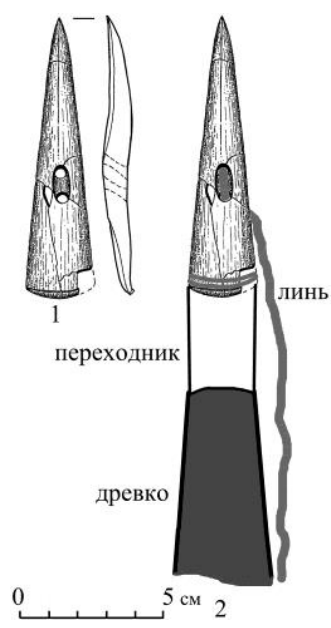

Рисунок 7 - 1 - клювовидный гарпун из «клада» № 3 стоянки Сахтыш II; 2 - схема крепления гарпуна (рис. Е.Л. Костылёвой)
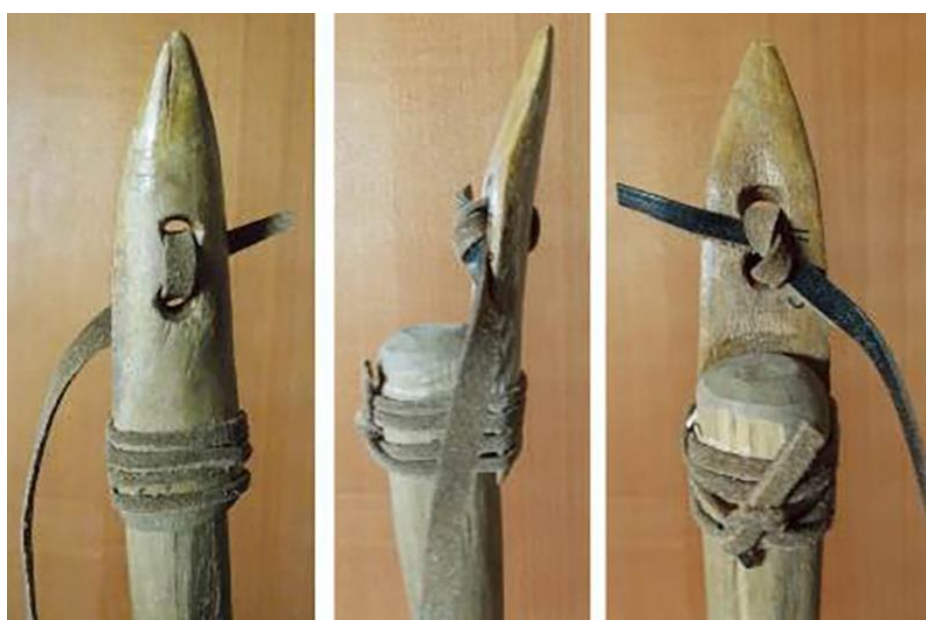

Рисунок 8 - Экспериментальное крепление клювовидного гарпуна со стоянки Сахтыш I к переходнику (фото Е.Л. Костылёвой) 
Костылёва Е.Л., Мацане А.

Клювовидные предметы и орудия рыбной ловли из ритуальных «кладов»... 07.00 .00 - исторические науки и археология

Заметим, что еще Д.А. Крайнов, рассматривая многообразие орудий рыболовства у неолитических племен Верхнего Поволжья, указывал, что «возможно ... существовали и другие орудия индивидуального лова рыбы, которые до нас не дошли, или орудия, которые мы относим к другим хозяйственным изделиям» $[17$, с. 144$]$. К таковым мы и можем отнести обозначенные выше клювовидные гарпуны. Заметим, что по количеству (7 экз.) эти предметы стоят на втором месте после зубчатых острий (9 экз.).

Почти все предметы из «кладов» несут в той или иной степени выраженные следы воздействия огня, т.к. особенностью ритуала создания «кладов» было разведение над ямкой с орудиями костра. Степень обгорания орудий была разной и зависела от глубины их залегания по отношению к уровню разведения костра. Располагавшиеся ближе к поверхности костяные орудия вследствие сильного нагрева кальцинировались и приобретали белесый оттенок (от чисто белого до серого). Располагавшиеся ниже приобретали черный цвет - полностью или частично.

Ни в одном из «кладов» нет полного набора орудий индивидуального лова рыбы. Наибольшее разнообразие, включающее 3 и 4 наименования орудий, представлено в двух кладах - №№ 8 и 12 (см. табл. 1).

Таблица 1 - Распределение орудий по «кладам»

\begin{tabular}{|c|c|c|c|c|c|c|}
\hline $\begin{array}{c}\text { № «клада» } \\
\text { и год } \\
\text { раскопок }\end{array}$ & $\begin{array}{l}\text { Зубчатое } \\
\text { острие }\end{array}$ & Гарпун & $\begin{array}{c}\text { Обломки } \\
\text { гарпунов } \\
\text { и острий }\end{array}$ & Крючок & $\begin{array}{c}\text { Клювовидный } \\
\text { гарпун }\end{array}$ & Всего \\
\hline $1-1984$ & 1 (рис. 4: 1) & & & & & 1 \\
\hline $2-1984$ & & & 1 (рис. $4: 12$ ) & & & 1 \\
\hline $3-1984$ & & & & & 1 (рис. 4: 18) & 1 \\
\hline $8-1984$ & 1 (рис. 4: 3) & 1 (рис. 4: 2) & & & 2 (рис. $4: 14,17)$ & 4 \\
\hline $10-1985$ & & & & & $\begin{array}{l}2 \text { (рис. } 4: 19,20 \text {; } \\
\text { рис. } 5 \text { ) }\end{array}$ & 2 \\
\hline $12-1964$ & & 1 (рис. 4: 11) & 1 (рис. 4: 5) & 1 (рис. 4: 4) & 1 (рис. 4: 16) & 4 \\
\hline $17-1966$ & 3 & 1 & & & & 4 \\
\hline $18-1963$ & 4 (рис. $4: 7-10$ ) & & & & & 4 \\
\hline $20-1963$ & & & & & 1 (рис. 4: 15) & 1 \\
\hline Всего & 9 & 3 & 2 & 1 & 7 & 22 \\
\hline
\end{tabular}

В «кладе» № 8 находились зубчатое острие, гарпун и два клювовидных гарпуна, а в «кладе» № $12-$ гарпун, обломок гарпуна или зубчатого острия, рыболовный крючок и клювовидный гарпун.

Рыболовный крючок из «клада» № 12, предназначенный для ловли крупной рыбы, уникален (рис. 4: 4). Его длина 92 мм. На тулове крючка расположены два дополнительных мелких зубца, направленных остриями вниз. Рыболовные крючки в «кладах» - чрезвычайно редкое явление. Еще один - составной крючок - был найден в «кладе» на стоянке Володары [14, с. 108 , рис. 5: 3].

Зубчатые острия (9 экз.) были обнаружены в четырех «кладах» - №№ 1, 8, 17 и 18. Половина из них - в обломках (в основном это насады). Среди них выделяется массивный роговой гарпун из первого клада с тремя редко поставленными клювовидными зубцами (рис. 4: 1). Длина его 257 мм. Он имеет круглый в сечении стержень, трехступенчатый насад, который со стороны крепления к древку уплощен. Аналогов подобному острию ни на одном поселении волосовской культуры неизвестно.

Изяществом форм и обработки отличаются четыре острия из клада № 18. Длина их от 175 до 248 мм. Количество зубцов - от 3-х до 5-ти. Сечение подокруглое, насад уплощен и оформлен одним-двумя вырезами для крепления (рис. 4: 7-10). Подобным же образом оформлены три небольших обломка насадов из «клада» № 17. Такие типы острий встречаются наиболее часто также и в культурном слое памятника.

Гарпунов обнаружено всего 3 - в «кладах» № 8 (целый), № 12 (почти целый) и № 17 (обломок насада). Два первых - достаточно крупные, третий, судя по обломку, - небольшой. Гарпун из восьмого клада длиной 215 мм изготовлен из широкой стенки трубчатой кости лося, имеет три клювовидных зубца и просверленное отверстие для привязывания линя (рис. 4: 2). Трехзубым был, видимо, и гарпун из 12-го клада (рис. 4: 11).

Разнообразие размеров и форм орудий рыболовства может говорить о специализации в этой области. При ловле крупной рыбы (сом, осетр, щука) использовали крупные крючки, гарпуны и острия, служившие, видимо, наконечниками острог. Согласно определениям Е.А. Цепкина, выполненным в 1960-е годы и хранящимся в архиве Д.А. Крайнова в научно-вспомогательном фонде Археологического музея Ивановского государственного университета, сомы, водившиеся в оз. Сахтыш, достигали длины 2 м, щуки -1 м, осетры -70 см.

Представленные в «кладах» орудия позволяют осторожно относиться к высказанному в свое время Д.А. Крайновым мнению, что характерной чертой гарпунов волосовской культуры (к гарпунам Д.А. Крайнов относил и зубчатые острия) является уплощенность $[17$, с. 142]. Возможно, это положение применимо лишь к ранне-волосовскому времени.

Время сокрытия «кладов», а значит, и бытования подобных орудий рыболовства определяется радиокарбоновыми датами по образцам угля из ритуальных кострищ: $3820 \pm 40,3900 \pm 40$ и $4190 \pm 50$ ВР (Ле-2617, 2613, 2615) [26; 27]. Однако по костям животных (медведь и барсук) из двух «кладов» (№№ 9 и 11) в 2017 году в лаборатории Белфаста были получены новые AMS даты: $4730 \pm 41$ и $4445 \pm 37$ [28, c. 146]. Достаточно существенное различие новых дат с предыдущими может быть связано с резервуарным эффектом, обусловленным тем, что в рационе питания этих всеядных животных присутствовала и рыба. А также, возможно, с тем, что «клад» № 9 является не ритуальным, а, согласно нашей типологии, «закладным» [15]. Он помещен в углу жилища, стена которого перекрыта финально-волосовским захоронением № 15 (рис. 3). «Клад» № 11 расположен вне 
зоны основных ритуальных площадок с «кладами» и также может относиться к более раннему времени. Этот «клад» отличается от прочих и тем, что он единственный из всех - был засыпан охрой и не имел следов воздействия огня. AMS-дата этого «клада» очень близка датам, полученным по углю из жилищ, предшествующих появлению могильника и ритуальных «кладов» финала развития волосовской культуры: $4470 \pm 80$ ВР и $4320 \pm 80$ ВР (Ле-1892, 1893) [29, c. 181].

Таким образом, финальный этап развития волосовской культуры отмечен большим разнообразием орудий индивидуального рыболовства: рыболовные крючки, гарпуны, зубчатые острия, а также клювовидные гарпуны. Последние - предшественники поворотных гарпунов. Они могли использоваться при лове как крупной рыбы, так и бобров. Некоторые из орудий уникальны (острие из «клада» № 1). Вместе с тем отмечается и стандартизация орудий (острия из «клада» № 18).

Ритуальные «клады» волосовской культуры - феноменальное явление, требующее дальнейшего изучения их состава, хронологии и назначения ряда вещей. В конечном итоге это позволит приблизиться к правильному пониманию как идеологических, так и хозяйственных структур людей, живших «на грани эпохи камня и металла». Эта эпоха прекрасно представлена в материалах средневолжских памятников волосовской культуры в недавно опубликованной обобщающей монографии В.В. Никитина [30]. К сожалению, подобные капитальные работы по волосовской культуре Верхнего Поволжья еще не написаны, хотя уже и сейчас можно найти точки соприкосновения материалов этих двух поволжских регионов. Однако приходится констатировать, что на средневолжских памятниках волосовской культуры практически не сохраняются изделия из кости, поэтому искать соответствия можно только среди кремневых/каменных орудий и керамики.

Отметим, что от «кладов», найденных на других памятниках волосовской культуры (Володары, Сахтыш VIII и др.), «клады» Сахтыша II отличаются своей представительностью и разнообразием как по номенклатуре, так и по материалу изготовления [13, c. 35-36, табл. 4]. Это увеличивает возможности для проведения их всестороннего анализа, сопоставлений и интерпретаций.

\section{Список литературы:}

1. Гадзяцкая О.С. Костяные изделия стоянки Сахтыш II // Краткие сообщения Института археологии. 1966. Вып. 106. С. 16-26.

2. Костылёва Е.Л. Остатки ранненеолитической верхневолжской культуры на стоянке Сахтыш II // Краткие сообщения Института археологии. 1984. Вып. 177. С. 47-52.

3. Гадзяцкая О.С., Крайнов Д.А. Новые исследования неолитических памятников Верхнего Поволжья // Краткие сообщения Института археологии. 1965. Вып. 100. С. 29-39.

4. Крайнов Д.А. Волосовская культура // Археология СССР: Эпоха бронзы лесной полосы СССР. М.: Наука, 1987. С. 10-28.

5. Крайнов Д.А. Русская равнина, Центр // Искусство каменного века (Лесная зона Восточной Европы). М.: Наука, 1992. С. 68-111.
6. Костылёва Е.Л., Уткин А.В., Календарная символика волосовского сосуда со стоянки Сахтыш II // Тверской археологический сборник. Тверь, 1996. Вып. 2. С. 299-304.

7. Уткин А.В., Костылёва Е.Л. Волосовские погребальные «святилища» Сахтышских стоянок // Каменный век европейских равнин: Объекты из органических материалов и структура поселений как отражение человеческой культуры. Сергиев Посад, 2001. C. 227-231.

8. Костылёва Е.Л., Тарасов А.Ю., Уткин А.В. Импортные орудия русско-карельского типа из раскопок Сахтышских стоянок: стратиграфия, планиграфия, хронология // Вестник Ивановского государственного университета. 2014. Вып. 3. С. 34-41.

9. Крайнов Д.А. Новые исследования стоянки Сахтыш II // Краткие сообщения Института археологии. 1982. Вып. 169. С. 79-86.

10. Крайнов Д.А. О религиозных представлениях племен волосовской культуры // Древности славян и Руси. М.: Наука, 1988. С. 38-44.

11. Крайнов Д.А., Костылёва Е.Л., Уткин А.В. Льяловские погребения на стоянке Сахтыш II // Археологические памятники Волго-Клязьминского междуречья. Иваново, 1990. Вып. 4. С. 27-31.

12. Алексеева Т.И., Денисова Р.Я., Козловская М.В., Костылева Е.Л., Крайнов Д.А., Лебединская Г.В., Уткин А.В., Федосова В.Н. Неолит лесной полосы Восточной Европы: Антропология Сахтышских стоянок. М.: Научный мир, 1997. 191 с.

13. Костылёва Е.Л., Уткин А.В. Нео-энеолитические могильники Верхнего Поволжья и Волго-Окского междуречья: Планиграфические и хронологические структуры. М.: ТАУС, 2010. 300 с.

14. Цветкова И.К. Ритуальные «клады» стоянки Володары // Памятники древнейшей истории Евразии. М.: Наука, 1975. С. 102-111.

15. Костылёва Е.Л., Уткин А.В. Волосовские «клады» стоянок Сахтыш II и VIII: планиграфия, структура, значение // Неолитические культуры Восточной Европы: хронология, палеоэкология, традиции: мат-лы межд. науч. конф., посв. 75-летию В.П. Третьякова / ред. В.М. Лозовский, О.В. Лозовская, А.А. Выборнов. СПб.: ИИИМК РАН, 2015. С. 109-114.

16. Костылёва Е.Л., Уткин А.В. Волосовские ритуальные клады в составе погребальных комплексов (хронология и типология) // Тверской археологический сборник. Тверь: ООО «Издательство «Триада», 2011. Вып. 8. T. І. С. 340-360.

17. Крайнов Д.А. Рыболовство у неолитических племен Верхнего Поволжья // Рыболовство и морской промысел в эпоху мезолита - раннего металла. Л.: Наука, 1991. С. 129-152.

18. Лозовская О.В., Лозовский В.М. Костяной и каменный инвентарь льяловского слоя стоянки Замостье 2: попытка вычленения // Неолитические культуры Восточной Европы: хронология, палеоэкология, традиции: мат-лы междунар. науч. конф., посв. 75-летию В.П. Третьякова / ред. В.М. Лозовский, О.В. Лозовская, А.А. Выборнов. СПб.: ИИИМК РАН, 2015. C. 101-105.

19. Кашина Е.А. Лук в энеолите Центра Русской равнины // Тверской археологический сборник. Тверь: ООО «Издательство «Триада», 2018. Вып. 11. C. 486-493. 
20. Гадзяцкая О.С., Крайнов Д.А. Энеолитическое поселение Стрелка I в бассейне р. Клязьма // Российская археология. 2002. № 2. С. 111-131.

21. Сидоров В.В. Манок - музыкальный инструмент эпохи неолита // Народные музыкальные инструменты и инструментальная музыка. Ч. 1. М., 1987. C. $157-163$.

22. Мачинский А.В. Древняя эскимосская культура на Чукотском полуострове // Краткие сообщения Института истории материальной культуры. 1941. Вып. IX. C. 80-90.

23. Гурина Н.Н. Рыболовство и морской промысел на Кольском полуострове // Рыболовство и морской промысел в эпоху мезолита - раннего металла. Л.: Наука, 1991. С. 164-181.

24. Сахалинский областной краеведческий музей [Электронный ресурс] // http://special.sakhalinmuseum.ru.

25. Winged Object (harpoon butt) [El. resource] // Brooklyn Museum. - https://brooklynmuseum.org/ opencollection/objects/89599.

26. Крайнов Д.А., Зайцева Г.И., Костылёва Е.Л., Уткин А.В. Абсолютная хронология Сахтышских стоянок // Археологические памятники Волго-Клязьминского междуречья. Иваново, 1991. Вып. 5. С. 33-42.

27. Костылёва Е.Л., Уткин А.В. Хронология погребального обряда волосовской культуры на терри- тории Верхнего Поволжья и Волго-Окского междуречья // Труды II (XVIII) Всероссийского археологического съезда в Суздале. М., 2008. Т. I. С. 230-233.

28. Костылёва Е.Л., Мацане А. Орудия рыбной ловли из ритуальных «кладов» волосовской культуры со стоянки Сахтыш II Центральной России // Стратегии жизнеобеспечения в каменном веке, прямые и косвенные свидетельства рыболовства и собирательства: мат-лы междунар. конф., посв. 50-летию В.М. Лозовского / под ред. О.В. Лозовской, А.А. Выборнова и Е.В. Долбуновой. СПб.: ИИМК РАН, 2018. C. $144-148$.

29. Костылёва Е.Л., Уткин А.В. Проблема пространственно-хронологического соотношения поселений и могильников волосовской культуры (по материалам поселений Сахтыш II, IIA и VIII) // Археология озерных поселений IV-II тыс. до н.э.: хронология культур и природно-климатические ритмы: мат-лы междунар. конф., посв. полувековому исследованию свайных поселений на северо-западе России. СанктПетербург, 13-15 ноября 2014 г. СПб.: Изд-во ООО «Периферия». С. 179-183.

30. Никитин В.В. На грани эпохи камня и металла. Средневолжский вариант волосовской культурноисторической общности. Йошкар-Ола, 2017. 765 c.

\section{CORACOID ARTEFACTS AND FISHING IMPLEMENTS OF THE VOLOSOVO CULTURE RITUAL «HOARDS» FROM SITE SAKHTYSH-II (CENTRAL RUSSIA)}

(C) 2018

Kostyleva Elena Leonidovna, candidate of historical sciences, associate professor of Russian History Department Ivanovo State University (Ivanovo, Russian Federation)

Matsane Aiya, postgraduate student of Historical Faculty University of Gothenburg (Gothenburg, Kingdom of Sweden)

Abstract. Sakhtysh II burial ground (Central Russia) belongs to the final stage of the Eneolithic Volosovo culture evolution. The Upper-Volga expedition IA RAS conducted the research there during 1960-1980. About twenty ritual «hoards» were discovered at Sakhtysh II consisting of artifacts clusters with traces of fire exposure. Among them there is a variety of fishing tools: serrated edges, harpoons, fishing hooks. We believe that the coracoid artefacts made of bone, the purpose of which is still debated, are also harpoons. The variety of the fishing tools forms allow us to speak about the specialization in fishing. Time of use of these «hoards» is based on coal samples from the ritual hearths which have been determined by radiocarbon dates: $3820 \pm 40,3900 \pm 40,4190 \pm 50 \mathrm{BP}$ (Le-2617, 2613, 2615). However, dating of animal bones (bear and badger) from two «hoards» (№ 9 and 11) in 2017 at the Belfast laboratory provided new AMS dates: $4730 \pm 41$ and $4445 \pm 37$. The significant difference between new and previous dates may depend on the reservoir effect, due to the fact that the diet of these omnivorous animals included fish as well as the fact that these two «hoards» were located outside the main ritual areas, belonging to an earlier time.

Keywords: Central Russia; Ivanovo Region; Eneolithic; Volosovo culture; Sakhtysh-II burial ground; ritual hoards; fishing tools; fishing hooks; harpoons; coracoid artefacts of unknown purpose; radiocarbon dates; problem of dates validity; reservoir effect.

УДК 902.652

DOI 10.24411/2309-4370-2018-14208

Статья поступила в редакцию 30.08.2018

\section{СТАТИСТИЧЕСКАЯ МОДЕЛЬ РАДИОУГЛЕРОДНОЙ ХРОНОЛОГИИ НЕОЛИТИЧЕСКИХ ПАМЯТНИКОВ ЛЕСОСТЕПНОГО ЗАВОЛЖЬЯ}

(C) 2018

Ставицкий Владимир Вячеславович, доктор исторических наук,

профессор кафедры всеобщей истории и обществознания

Пензенский государственный университет (2. Пенза, Российская Федераџия)

Аннотация. В статье рассматривается хронология памятников раннего неолита лесостепного Заволжья, которая опирается на радиоуглеродные определения, полученные по фрагментам керамики. Радиоуглеродные даты по памятникам елшанской и средневолжской культур собраны в две таблицы. В них графически представлен вероятностный интервал для каждой даты. За условную статистическую единицу принят хронологический интервал продолжительностью 125 лет. На основе статистических данных автором построены 